Article

\title{
Modeling the Movement of Septic Water Chloride through a Soil Profile
}

\author{
Shawkat Kochary ${ }^{1, *}$, Tom Byl ${ }^{2}$ and Bahzad Noori ${ }^{1}$ \\ 1 Department of Civil Engineering, University of Duhok, Duhok City 42001, Kurdistan Region, Iraq; \\ bahzad.mohammed@uod.ac \\ 2 Department of Agriculture Sciences, Tennessee State University, Nashville, TN 37209, USA; \\ tdbyl@yahoo.com \\ * Correspondence: Shawkat@uod.ac; Tel.: +964-750-302-7515
}

Academic Editor: Vincenzo Torretta

Received: 8 January 2017; Accepted: 16 March 2017; Published: 27 March 2017

\begin{abstract}
The purpose of this study was to investigate the movement of chloride through a vadose zone located under failed and non-regulated septic tanks of Duhok city, Kurdistan of Iraq, potentially contaminating its groundwater. A physical vadose model (PVM) of a vertical flow direction was built in the laboratory to represent the city soil profile. The size of the PVM was $210 \times 122 \times 9.7 \mathrm{~cm}$ (height, width, and depth). Preliminary soil tests were conducted to better represent the lithology of study area. The PVM was then packed with regional silt clay soil, after modifying its texture, using an innovative packing procedure to preserve natural soil density and porosity. The model was run for a period of three months with newly collected septic water (black water from a septic tank) as an exclusive source of contaminants. Water samples from eight vertically arranged portals representing $12.5,37.5,62.5,87.5,112.5,137.5,162.5$, and $187.5 \mathrm{~cm}$ levels in the subsurface soil profile were collected on a daily basis and analyzed weekly. Logistic regression and logarithmic models were developed to spatially predict the movement of chloride ions at different sampling depths in the soil profile until the system had reached the equivalent chloride concentration of the septic water or had stabilized. There was a good agreement between the physical model and the statistical models, however each model had its strengths and weaknesses. This study demonstrated that there is a potential for septic water to reach the water table within a 2-3 weeks period. Dilution and dispersion appear to play important roles in the fate and transport of septic water. This study has the potential to help the local authorities predict percolation rates and establish strategies for groundwater management in order to protect the public health.
\end{abstract}

Keywords: chloride ion; septic tank; groundwater; physical vadose model (PVM); logistic models; logarithmic models

\section{Introduction}

As world population grows, the demand for water increases to provide for human consumption, irrigation and other municipal services. Groundwater in many areas around the world (including this study area) has become an alternative source of water that people rely on. However, simply because it is groundwater does not mean it is safe. Human activities and natural cycles sometimes introduce contaminants to the subsurface and into the aquifer. Once there, contamination is difficult and costly to clean [1]. This is true especially near or under the populated territory, which tends to be affected by pollution from different sources [2]. Protecting groundwater has become a very important environmental discipline to minimize the contamination in aquifers and maintain safe water supplies. Methods that have been used to protect groundwater include reduction in pumping, reducing recharge in problem areas with capping or diversions, using natural attenuation processes and improved 
infrastructure to prevent leaks [3]. When considering the health of an aquifer, it is necessary to study all processes involved in the hydrological cycle, from the recharge of groundwater to the discharge, because contamination risk or exchange of dangerous substances can occur in each stage [4]. Failure to protect groundwater from contamination poses a serious threat to both human health and the environment [5]. One of the most frequently reported causes of groundwater contamination related to water-borne diseases caused by bacteria and viruses are septic systems [6]. One important factor influencing groundwater contamination from septic systems is the density and type of septic systems in an area $[6,7]$.

When the septic density is on a lot size ranging from less than one quarter acre to three acres $\left(\approx 1000 \mathrm{~m}^{2}-12,000 \mathrm{~m}^{2}\right)$ with neighbors bordering the lots, it is considered a high septic tank density area [3]. Accordingly, Duhok city is classified as having a very high density of septic tanks, with an average lot size of $300 \mathrm{~m}^{2}$. The public in Duhok city have become more educated about water quality and concerned about the dangers of unregulated septic systems at such a high density. Hence, the need for this project to address the growing concern for septic contamination and to gain a better understanding of the role the vadose zone contributes to septic contamination of the groundwater aquifer. This research was conducted to monitor the movement of chloride ions, as an indicator of septic water, discharged directly from failed and non-regulated septic tanks seeping through the soil profiles, as well as, to create prediction models that could be used by local authorities to establish strategies for groundwater management in order to protect public health.

As per the physical model design, many types of physical facsimiles can be made to simulate groundwater and/or septic water flow through unsaturated or saturated soils and rocks. For example Humphrey, 1992 [8] has developed and constructed a large-scale physical aquifer model to conduct transport experiments under controlled conditions to evaluate groundwater remediation strategies in contaminated porous media. Humphrey used a non-reactive bromide and blue dye as tracers in conducting the experiments. Ojuri and Ola 2010 [9] have designed a three-dimensional laboratory-scale sand tank (aquifer) model to investigate the transport of contaminated groundwater within the tropical aquifer material and the rate at which contaminants spreads both longitudinally and transversely. In their study, chloride was used as an inorganic tracer. Mastrocicco et al., 2011 [10] used a large tank filled with soil with piezometers at different depths to collect water samples; Aquilanti et al., 2013 [11] and Tazioli and Palpacelli 2013 [12] used plexiglas columns and batch tests filled with carbonate rocks and groundwater with chemical tracers. It was recognized that designing such a physical vadose-zone model packed with a low-porosity medium has not yet received a lot of attention, possibly due to some difficulties; issues such as homogeneous packing process, model draining process and satisfaction with soil hydrogeological parameters such as soil bulk density, permeability and effective porosity. For this research, a large-scaled physical vadose model with a vertical flow direction was designed. The model was packed with one homogeneous layer of silt clay soil that represented the homogenous lithology of the $100 \mathrm{~m}$ vadose zone in the study area. Preliminary in situ soil tests were conducted to better understand and represent the lithology of study area. These preliminary tests were used in the PVM design as described in the methods section. Several different soil-packing processes were assessed to achieve the best subsurface replication for the Duhok region. As per selection of the tracer to evaluate the fate and transport of septic waters in the vadose zone, there are many to choose from in the literature. Anionic tracers (such as $\mathrm{Cl}^{-}, \mathrm{Br}^{-}, \mathrm{I}^{-}$) have been widely used by groundwater hydrologists for many years because of their low susceptibility to adsorption or ion exchange processes on vadose and aquifer materials. Organic dyes have been used extensively as tracers because they are detectable even after moderate dilution and are measureable in very low concentration using fluorometers. However, the strong sorptive tendencies of most organic dyes limit their general application largely to karst areas were groundwater primarily moves by conduit flow [13]. Kanwar, 1996 [14] conducted studies to evaluate the effectiveness of chloride, bromide, lithium, fluoresceine dye and rhodamine WT dye for tracing the movement of agricultural chemicals to groundwater. Chloride was selected as the preferred tracer to describe the movement of $\mathrm{NO}_{3}-\mathrm{N}$ 
in the vadose zone over the other potential tracers because it behaved much like the nitrate in the subsurface. For this research project, black water from a septic tank was the experimental water used to study the fate and transport of septic wastes through the vadose zone. Chemicals in septic waters that have the potential to serve as tracers include different surfactants, optical brighteners in laundry detergents, common disinfectants such as quaternary ammonia compounds, fecal bacteria, nitrogenous compounds and different salts. Our selection criteria of a septic-water tracer considered the consistent occurrence in septic water, analytical costs, and whether it was a conservative tracer that resisted potential sorption and biological transformation. The salt anion chloride was selected because it is highly mobile and not subject to adsorption, biodegradation, biological transformation, ion exchange or oxidation-reduction reactions [15]. The results of this study using chloride as a tracer in the PVM would allow us to improve our comprehension of how septic waters move vertically through the vadose zone to the water table below the city of Duhok.

\section{Materials and Methods}

\subsection{Study Location}

Duhok city is located in the north part of the Kurdistan region of Iraq. It encompasses approximately $107 \mathrm{~km}^{2}$ with geographical coordinates of latitudes $36^{\circ} 50^{\prime} 00^{\prime \prime}-36^{\circ} 54^{\prime} 40^{\prime \prime}$ North, and longitudes $42^{\circ} 52^{\prime} 00^{\prime \prime}-43^{\circ} 04^{\prime} 44^{\prime \prime}$ East [16]. The city has two aquifers; an upper aquifer, which is unconfined and composed of sedimentary rocks of Paleocene-Lower Eocene to Holocene age and a lower aquifer, which is confined and represents Pila Spi Formation. Both aquifers are separated by the lower Fars Formation [17]. The city is in a valley between two mountain chains; Bekhair anticline at the north with surface altitude of $1050 \mathrm{~m}$ above sea level, and Duhok anticline at the south with surface altitude of $900 \mathrm{~m}$ above sea level. The city's lowest elevation point is located at the southwest with surface altitude of $400 \mathrm{~m}$ above sea level (Figure 1). However, the city basin lies on an extended wide valley and is restricted by the two mentioned anticlines [17].

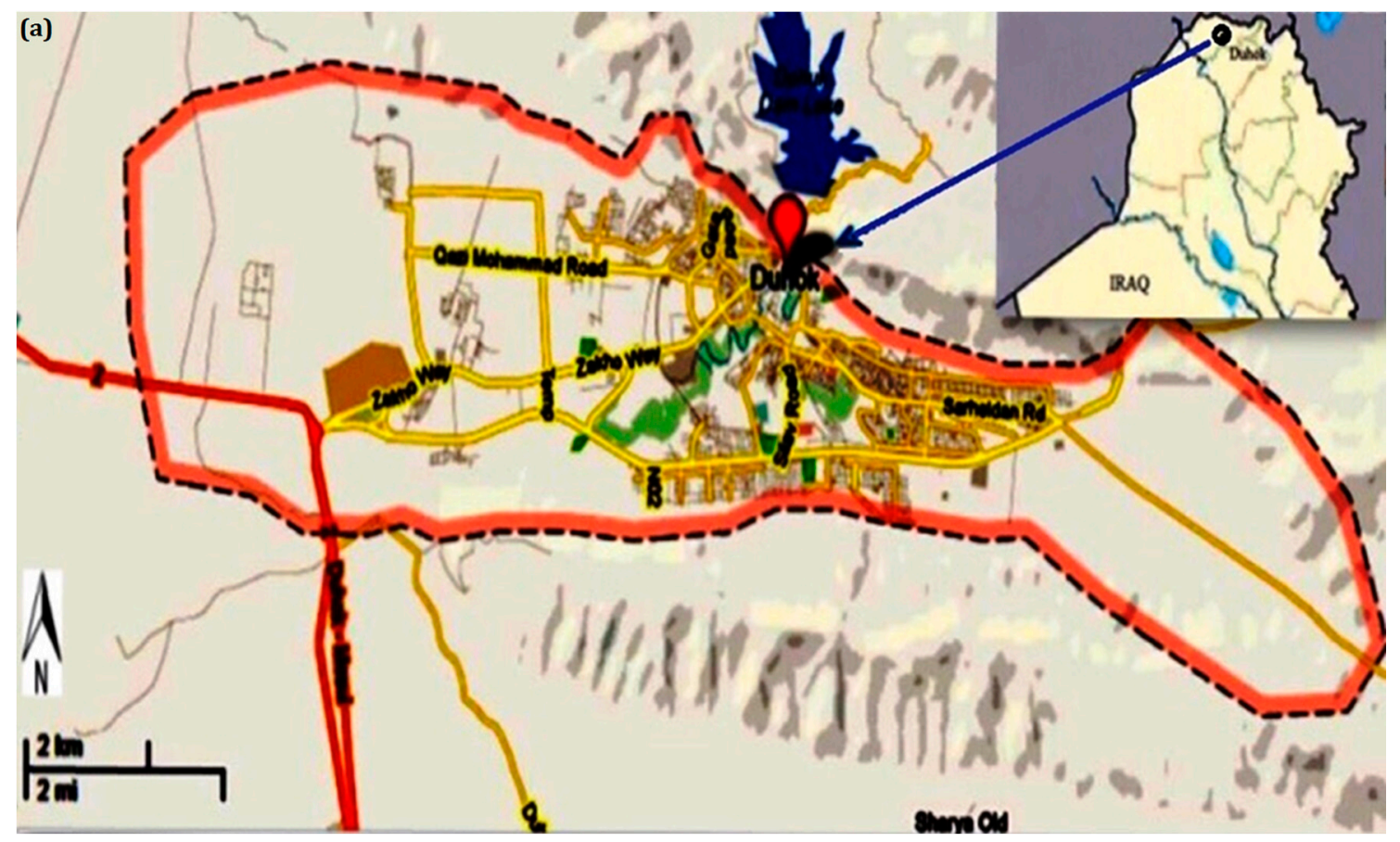

Figure 1. Cont. 


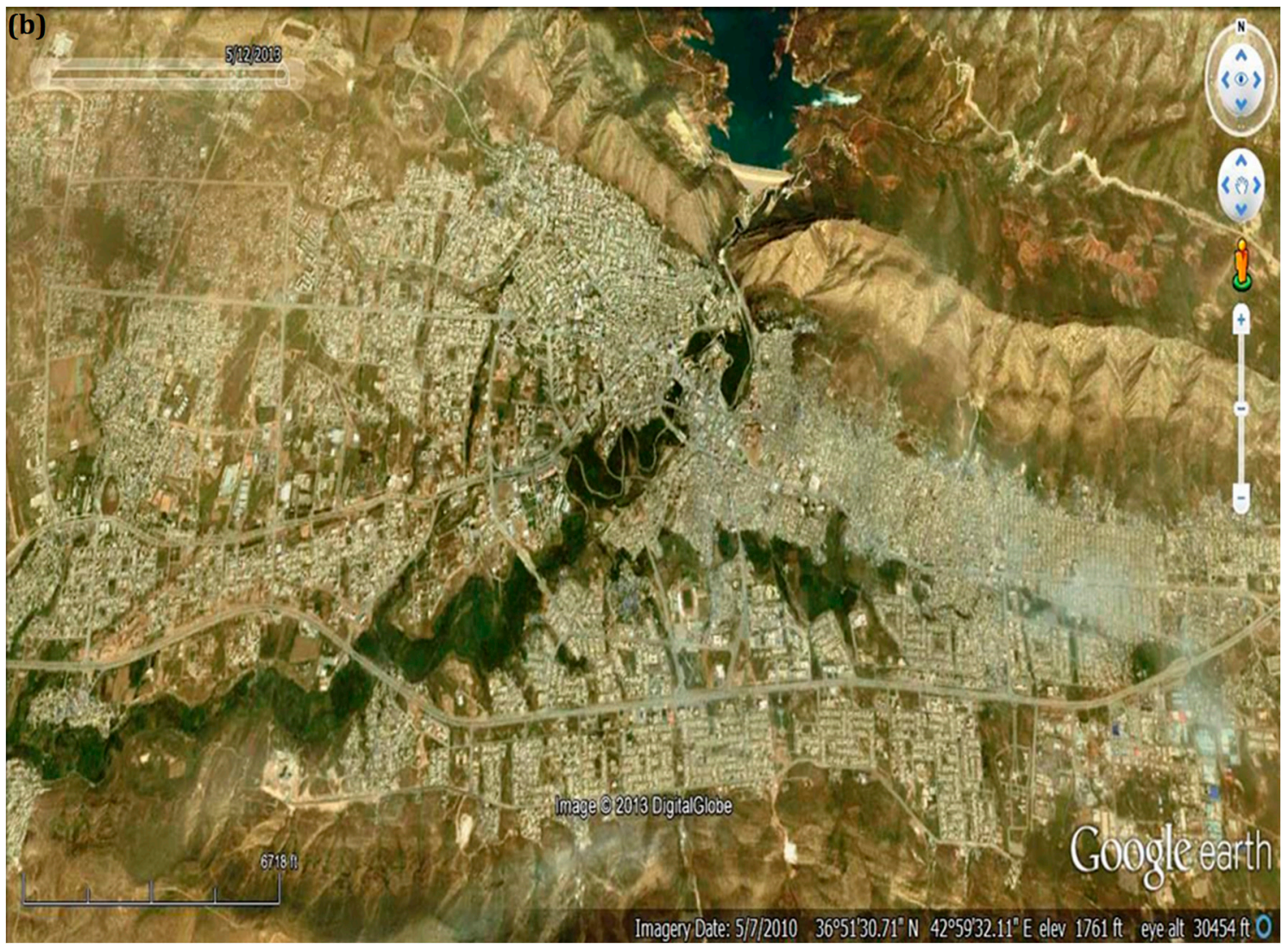

Figure 1. Sketch of the site location (a) and Satellite aerial view (b).

\subsection{Preliminary Tests}

Soil properties play an important role in contaminant fate and transport processes. Geological materials that represent regional vadose soil profiles were collected from a road-construction site that exposed $4 \mathrm{~m}$ depth during excavation in an uninhabited section near Duhok. Preliminary chemical tests for residual soil chloride and other constituents were conducted using methods published in the standard methods for the examination of water and wastewater [18]. Additional soil tests included: (1) In situ bulk density ( $\gamma$ bulk) and in situ dry density ( $\gamma$ dry) for the undisturbed soil using standard sand-cone replacement method (ASTM D1556), which resulted in $20.14 \mathrm{kN} / \mathrm{m}^{3}$ and $17.18 \mathrm{kN} / \mathrm{m}^{3}$ respectively; (2) Soil texture analysis (hydrometer analysis test ASTM D422) and Atterberg limits (ASTM D4318), which resulted in Low plasticity CLAY soil (CL) with liquid limit 34.5\%, plastic limit 22.3\%, and plasticity index (P.I. = L.L. - P.L.) of $12.2 \%$ according to Unified Soil Classification System (USCS ) (ASTM D-2487) for laboratory classification of fine-grained soil; (3) The optimum dry density, $\gamma$ dry, with optimum water content $(\omega)$ (ASTM D-698 of standard proctor compaction method), which resulted in $1725 \mathrm{~kg} / \mathrm{m}^{3}$ and $18.5 \%$ respectively; (4) The permeability coefficient factor $(\mathrm{k})$ (falling head test method), which was $0.044 \times 10^{-5} \mathrm{~cm} / \mathrm{s}\left(2.62 \times 10^{-5} \mathrm{~cm} / \mathrm{min}\right)$; (5) Specific gravity $\left(G_{s}\right)$ test (ASTM D854 standard test methods), which was 2.71 for silt clay soil and 2.63 for fine sand; (6) The porosity (n) of silt clay soil and dry sand, which resulted in 0.354 and 0.346 porosity respectively. Specific gravity and porosity for both silt clay soil and dry sand were within the typical ranges for silt clay soils [19]. 


\subsection{Physical Model Design}

Duhok city has an upper aquifer located at approximately $100 \pm 10 \mathrm{~m}$ below the surface with a measured hydraulic conductivity of 0.1-6.3 m/day, depending upon well location [17]. A large-scale physical vadose model (PVM), used to measure vertical flow of septic-tainted recharge water, was designed at a scale of 1:50. The PVM was designed with the following assumptions: (1) the water table is approximately $100 \mathrm{~m}$ below the surface; (2) Duhok has single residential houses with average lot size of $300 \mathrm{~m}^{2}$ and $15 \mathrm{~m}$ frontage and the houses are side-connected; (3) Every residential house has a septic tank (chamber) of $2 \times 3 \times 2.5 \mathrm{~m}$ for width, length, depth respectively with a $2 \mathrm{~m}$ head of septic water, which is necessary for water percolation through the soil; (4) The geology of the vadose zone is homogenous in texture with uniform density. Using these assumptions, the PVM dimensions were established at $200 \mathrm{~cm}$ height and $122 \mathrm{~cm}$ width and $9.7 \mathrm{~cm}$ thickness and was packed with a homogeneous layer. The septic system was designed to simulate five septic tanks in five side-by-side residential units. The simulated septic tanks were $4 \mathrm{~cm}$ in width and $6 \mathrm{~cm}$ in depth. Figure 2 presents the physical model design.
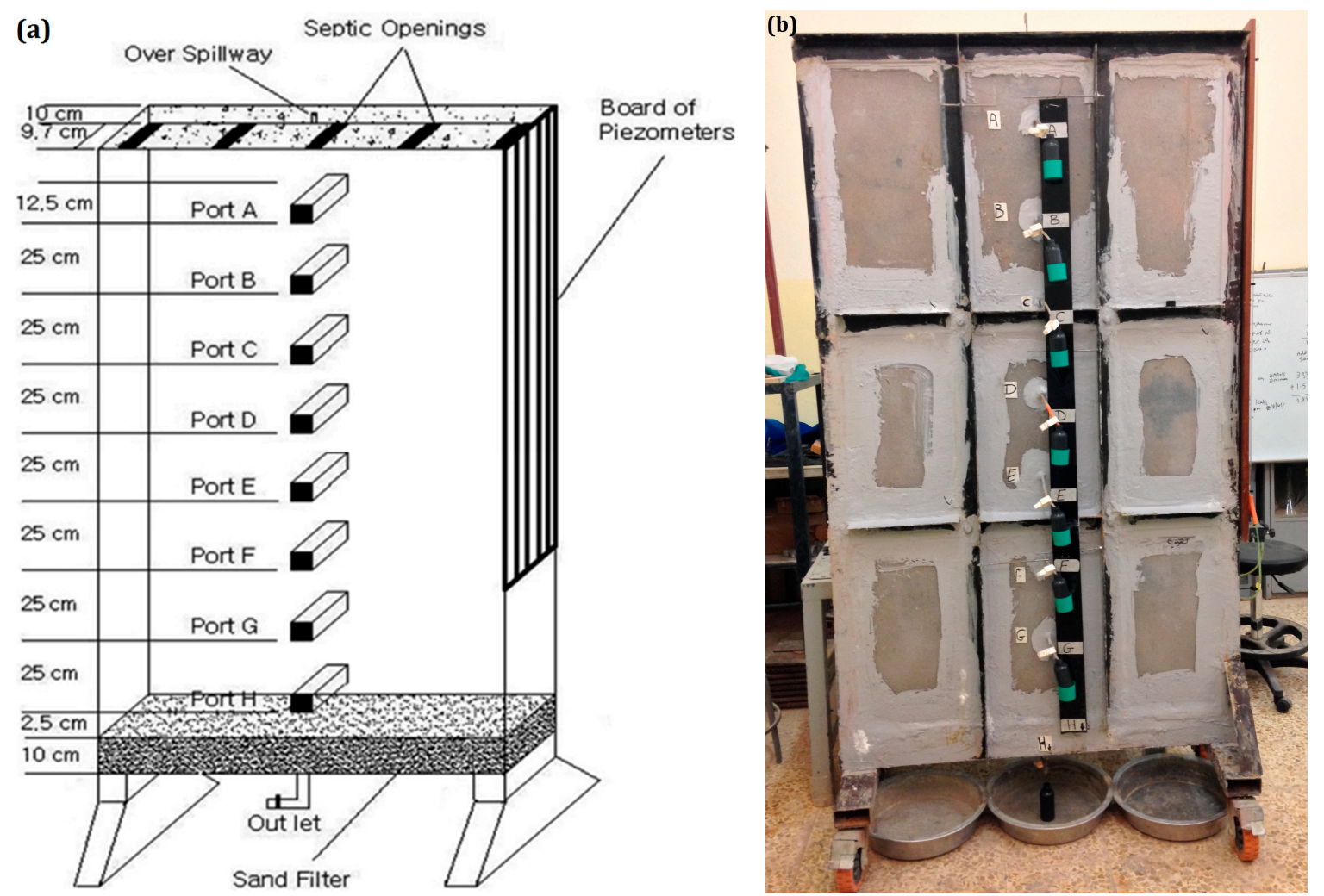

Figure 2. A non-scaled sketch (a) and a 1:50 scale Physical Model Design (b).

\subsubsection{Design of Model Frame}

The PVM was held together using an external steel frame with dimensions of $212 \times 123.5 \times$ $11.2 \mathrm{~cm}$ (height, width, and thickness respectively). The frame was designed and fabricated out of 3-inch tapered edge L-angle steel. The frame was supported by four M10 × $180(10 \mathrm{~mm} \times 180 \mathrm{~mm})$ galvanized hex bolts to resist the compaction effort and the heavy load of packing material as well. The model's internal dimensions were $210 \times 122 \times 9.7 \mathrm{~cm}$ (height, width, and depth respectively). 


\subsubsection{Design of Model Walls}

The walls of the PVM tank were made of Perspex Acrylic sheets (Plexi-glass) of $6 \mathrm{~mm}$ thickness. To eliminate the effect of smooth boundaries (model internal walls), it was decided to roughen the surface of the internal walls by applying multi-layers of antibacterial adhesive liquid mixed with fine sand whose particles passed sieve \#60 $(0.25 \mathrm{~mm})$ and remained on sieve \#100 $(0.149 \mathrm{~mm})$. The washed and dried fine sand was applied with the adhesive liquid to the internal walls surfaces using compressed air. The roughened internal surfaces of model walls were then lined (divided) to specify the occupancy volume of packing material in order to reach the desired density.

\subsubsection{Design of Sampling Ports}

Eight sampling ports of $2 \times 2 \times 9.5 \mathrm{~cm}$ were made out of perforated Acrylic (Plexi-glass sheets), connected to $3 / 16^{\prime \prime}$ ID vinyl-flex PVC plastic tubes, dressed by seamless knitted filter socks of 1 -inch size, and installed at levels $12.5,37.5,62.5,87.5,112.5,137.5,162.5,187.5 \mathrm{~cm}$ below the top. The 8 ports were labeled Port A through Port H. Using the 1:50 design, these portals in the PVM model would represent depths in the actual vadose zone of $6.25 \mathrm{~m}$ to $94 \mathrm{~m}$ below the surface.

\subsubsection{Installation of Piezometers}

Seven piezometers, which consisted of porous tips and clear rise pipes were installed at the same levels as the sampling ports and held on the side of the model in order to monitor the hydraulic gradient. Porous tips inserted into the PVM consisted of $9.5 \mathrm{~cm}$ perforated tubes connected to $1 / 4^{\prime \prime}$ ID vinyl-flex plastic tubes covered with 100-micron poly mesh bag filters. The rise pipes consisted of $3 / 16^{\prime \prime}$ ID vinyl-flex PVC clear plastic tubes fastened in a vertical direction, parallel to the PVM.

\subsubsection{Design of Septic Tanks}

Based upon the septic density assumptions and the adopted 1:50 scale, the PVM had five septic tanks of $4 \times 6 \times 6 \mathrm{~cm}$ width, length, and depth respectively. Preliminary percolation tests found a $4 \mathrm{~cm}$ head of septic water was required for water percolation into the PVM soil. In order to simplify the design of the septic systems, a single tank of $122 \mathrm{~cm}$ length $\times 6 \mathrm{~cm}$ thickness $\times 6 \mathrm{~cm}$ depth with five openings of $6 \mathrm{~cm}$ length and $4 \mathrm{~cm}$ width was fabricated, equivalent to five leaky septic tanks. This septic tank simulation was placed on top of the model. Using this single chamber to simulate 5 septic tanks provided a uniform hydraulic head and equal contact with the soil through the five openings. To satisfy the steady state flow condition in the model $\left(\right.$ flow $_{\text {in }}=$ flow $_{\text {out }}$ ), the hydraulic head in the single chamber was sustained by a continuous water feed that maintained water at $4 \mathrm{~cm}$ using an overflow spillway that left $2 \mathrm{~cm}$ as a free board.

\subsubsection{Design of Draining Filter}

In order to improve flow conditions and prevent fine-graded materials from permeation out of the model, a drain filter was designed following the general guide of BC Ministry of Agriculture, 2000 [20]. The designed drain filter satisfied both piping and permeability criteria established by Bertram, 1940 [21] in designing drain filters and is based upon Equations (1) and (2). In addition, it satisfied the two conditions suggested by U.S. Army corps of engineers [22] as in Equations (3) and (4).

$$
\begin{gathered}
\frac{D 15(\text { filter })}{D 15(\text { base })} \geq 4 \text { to } 5 \\
\frac{D 15(\text { filter })}{D 85(\text { base })}<4 \text { to } 5 \\
\frac{D 15(\text { filter })}{D 85(\text { base })} \leq 5
\end{gathered}
$$




$$
\frac{D 50(\text { filter })}{D 50(\text { base })} \leq 25
$$

D15 refers to grain size for which 15 percent of the material (by weight) is finer than the soil make-up, and $D 85$ is grain size for which 85 percent of material (by weight) is finer. For more details, refer to the Ph.D. dissertation of Kochary (2017) [23].

\subsubsection{Modification of Packing Material}

The texture of the packing material was modified in order to increase its hydraulic conductivity to ensure water sample collection under gravitational influence. Modification was made by replacing 20 percent (by weight) of the low-plasticity silt clay soil with fine sand whose particles passed through sieve \#30 and remained on sieve \#40. Hence, sand/clay ratio of 20/80 percent (by weight) for packing material was adopted. The model was then packed using 15 batches of the $20 / 80$ soil $(25 \mathrm{~kg})$ and a top layer $(2.5 \mathrm{~kg})$ of well-mixed sand / clay at the tank-soil interface (total $=377.5 \mathrm{~kg})$.

\subsubsection{Homogeneity of Model Packing}

To ensure that each of the $25 \mathrm{~kg}$ batches was packed into the PVM at the same density and porosity, the roughened internal walls of the model had lines inscribed onto them into equal partitions. These lines allowed us to add the $25 \mathrm{~kg}$ of soil, then pack it to an equal volume, thus assuring uniform density at each level. This packing procedure was efficient for providing not just a uniform density at each level, but also a reasonably consistent permeability (hydraulic conductivity) throughout the vertical distribution of the PVM. Tap water was poured into the PVM to a depth of $25 \mathrm{~cm}$ prior to placing the soil in the model. Twenty-five $\mathrm{kg}$ of soil material was spread uniformly into the water and pushed down very gently (to avoid breaking the bonds between soil particles) until it reached the designated line (i.e., achieved the desired volume equal to the desired soil density). The resulting turbid water left in the model was gently diluted with tap water to a free-standing depth of $25 \mathrm{~cm}$ before the next batch of soil material was added.

This process was repeated 15 times until the PVM chamber was filled with soil. The PVM chamber wall had to be cut into three accessible sections to facilitate homogeneous packing at every level. This modified packing procedure was a benefit because it allowed us to (1) inspect the PVM chamber for any leaks; (2) assess model body protection (as steady pressures were applied); (3) test the model components such as the sampling ports, piezometers, and drain filters; (4) achieve the desired soil density in a uniform fashion; (5) begin the experiment with field capacity soil (i.e., water saturation); (6) expedite the draining process; and (7) expedite steady state flow condition.

\subsubsection{Model Draining Process}

Upon packing process completion, the model was gently flushed to remove dissolved ions from the soils using tap water. A spillway was installed inside the artificial septic system at $4 \mathrm{~cm}$ to maintain steady hydraulic head, which was critical for a steady-state flow condition (flow in $=$ flow $_{\text {out }}$ ). The soil was flushed with tap water until the specific conductance of the water entering the system via the artificial septic system was almost the same value as the water discharging at the bottom. After four weeks of purging with tap water, preferential flow paths developed between some of the artificial septic openings and the soils and the specific conductance, $\mathrm{SC}_{\mathrm{in}}$, and $\mathrm{SC}_{\text {out }}$ were 530 and $620 \mu \mathrm{s} / \mathrm{cm}$, respectively. This helped to remove many of the residual soil salts that might interfere with the chloride measurements in the study.

\subsubsection{Model Running Process}

The experimental water used in this study was collected directly from septic tanks using a vacuum septic truck. A sufficient quantity was filtered and stored in $1.5 \mathrm{~L}$ plastic bottles, refrigerated at $4{ }^{\circ} \mathrm{C}$ and stored in the dark. In order to maintain a uniform percolation of septic waters into the PVM 
system, the artificial septic system was removed from the top and a daily supply of one $1.5 \mathrm{~L}$ bottle of filtered septic water was placed directly onto the soil. In the first day of running the model, tap water (on top) was replaced with two of $1.5 \mathrm{~L}$ bottles of septic water (total of $3.0 \mathrm{~L}$ ) and an initial set of $8 \times 180 \mathrm{~mL}$ of water samples from the eight sampling ports was immediately collected for chemical analysis (as a reference). Thereafter, there was a daily loading of a 1.5-L bottle of the septic water onto the PVM and collecting the sets of $8 \times 180 \mathrm{~mL}$ water samples continued for the duration of the model (91 days). Daily sets of $8 \times 180 \mathrm{~mL}$ water samples were collected within four hours after loading septic water. Samples were collected in $200 \mathrm{~mL}$ dark glass bottles and basic rules of sampling, handling, preservation, and analysis were followed.

\subsubsection{Methods of Analysis}

Water samples were collected and refrigerated on a daily basis and analyzed weekly for chloride ion concentration. Chlorine as chloride ion $\mathrm{Cl}^{-}$was determined by titration with silver nitrate $\mathrm{AgNO}_{3}$ and with potentiometric end-point detection using method 407C of American Public Health Association, 1998 [18]. Two statistical models, logistical regression and logarithmic, were developed from the resulting chloride data. Models for each portal were developed individually using MATLAB software to spatially predict chloride movement from the septic water to each of the different levels in the PVM.

\section{Results}

The average chloride ion, $\mathrm{Cl}^{-}$concentration of the filtered septic water used throughout this study was $12.5 \mathrm{meq} / \mathrm{L}$ (444 ppm). The background chloride ion concentration of tap water (initial set of time zero) and the 7-day $\mathrm{Cl}^{-}$concentrations at each respective port are reported in Table 1 . As time progressed, the concentration of chloride rose in the lower ports. The background chloride ranged from 32 to $56.8 \mathrm{mg} / \mathrm{L}$ initially. This variability within the system was probably due to residual chloride that had not been flushed out during the tap-water purge. However, since the chloride concentration in the experimental septic water was an order of magnitude higher $(444 \mathrm{mg} / \mathrm{L})$, this variability would not prevent interpretation of when the septic chloride initially appeared at the different port levels.

Table 1. Chloride ion concentration throughout model running process in $\mathrm{mg} / \mathrm{L}$ (ppm).

\begin{tabular}{ccccccccc}
\hline Days & Port A & Port B & Port C & Port D & Port E & Port F & Port G & Port H \\
\hline 0 & 42.6 & 46.2 & 32 & 56.8 & 46.2 & 35.5 & 39.1 & 39.05 \\
7 & 376 & 362 & 160 & 85.2 & 42.6 & 42.6 & 39.1 & 39.05 \\
14 & 373 & 337 & 252 & 131 & 92.3 & 49.7 & 32 & 49.7 \\
21 & 426 & 383 & 266 & 170 & 121 & 60.4 & 53.3 & 71 \\
28 & 355 & 295 & 206 & 135 & 85.2 & 56.8 & 63.9 & 85.2 \\
35 & 327 & 284 & 217 & 163 & 107 & 92.3 & 85.2 & 63.9 \\
42 & 327 & 348 & 227 & 206 & 192 & 92.3 & 63.9 & 85.2 \\
49 & 362 & 362 & 298 & 277 & 227 & 135 & 85.2 & 92.3 \\
56 & 355 & 334 & 305 & 291 & 241 & 135 & 85.2 & 99.4 \\
63 & 334 & 348 & 319 & 298 & 256 & 178 & 107 & 99.4 \\
70 & 362 & 312 & 341 & 284 & 270 & 206 & 114 & 114 \\
77 & 383 & 341 & 334 & 305 & 277 & 213 & 156 & 135 \\
84 & 369 & 362 & 327 & 383 & 305 & 227 & 156 & 149 \\
91 & 376 & 362 & 355 & 376 & 362 & 263 & 178 & 135 \\
\hline
\end{tabular}

\section{Development of Models}

Data from Table 1 were used to generate two different numerical models using statistical analysis (Table 2). A logistic regression and a logarithmic model were applied to the data. The mean was calculated using observed values from Table 1. The root-mean-square error (RMSE) represents the sample standard deviation of the differences between predicted values and observed values. The SD is the standard deviation for the data. 
Table 2. Descriptive statistics for the data used in generating the models.

\begin{tabular}{ccccccccc}
\hline Port & Mean & $\begin{array}{c}\text { Logistic Modeling } \\
\text { Confidence }\end{array}$ & RMSE & SD & Mean & $\begin{array}{c}\text { Logarithmic } \\
\text { Modeling Confidence }\end{array}$ & RMSE & SD \\
\hline A & 333.97 & $95 \%$ & 20.67 & 19.71 & 326.60 & $95 \%$ & 22.82 & 20.08 \\
B & 319.75 & $95 \%$ & 30.08 & 28.8 & 308.53 & $95 \%$ & 22.77 & 28.5 \\
C & 267.62 & $95 \%$ & 54.36 & 51.83 & 259.91 & $95 \%$ & 32.17 & 60.94 \\
D & 200.28 & $95 \%$ & 45.57 & 80.27 & 225.93 & $95 \%$ & 55.77 & 96.35 \\
E & 163.00 & $95 \%$ & 55.41 & 85.63 & 202.65 & $95 \%$ & 50.58 & 96.59 \\
F & 107.98 & $95 \%$ & 26.29 & 62.83 & 134.63 & $95 \%$ & 37.33 & 75.76 \\
G & 69.71 & $95 \%$ & 10.39 & 27.1 & 109.34 & $90 \%$ & 19.96 & 40.75 \\
H & 76.16 & $95 \%$ & 9.71 & 23.62 & 108.08 & $90 \%$ & 8.74 & 27.45 \\
\hline
\end{tabular}

RMSE: The standard deviation of the differences between predicted values and observed values. SD: standard deviations.

\subsection{Logistic Regression Models}

The first method we used to describe the movement of chloride ions through the soil profile was a logistic regression model developed for each of the eight different portals (increasing depth represented by Port A through Port H). Figure 3 represents the logistic regression models for all eight portals. The chloride concentrations in the upper portals tended to jump up quickly and hold steady. However, in portal D and lower, the chloride concentration is more sigmoidal through time. This shows there is dilution and dispersion mechanisms occurring in the soil matrix. The logistic model appears to do a good job describing the occurrence of chloride in the upper portals, but fails to capture the continuing rise in chloride in the lower portals. The goodness of fit $\left(\mathrm{r}^{2}\right)$ drops in the lower portals. Thus, it was appropriate to try a logarithmic model to see if that provided a better mathematical description of the chloride concentration in the lower portals through time.
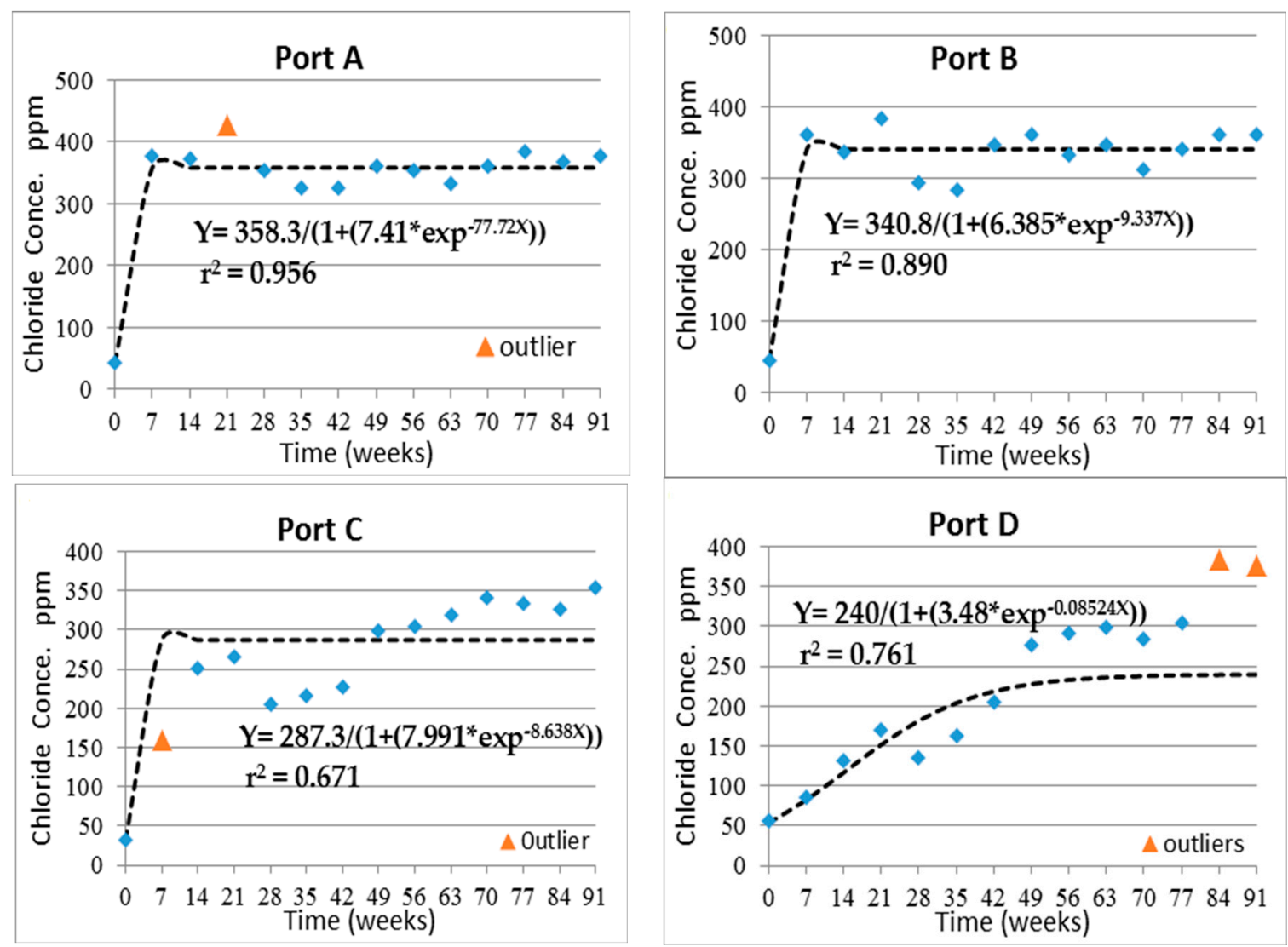

Figure 3. Cont. 

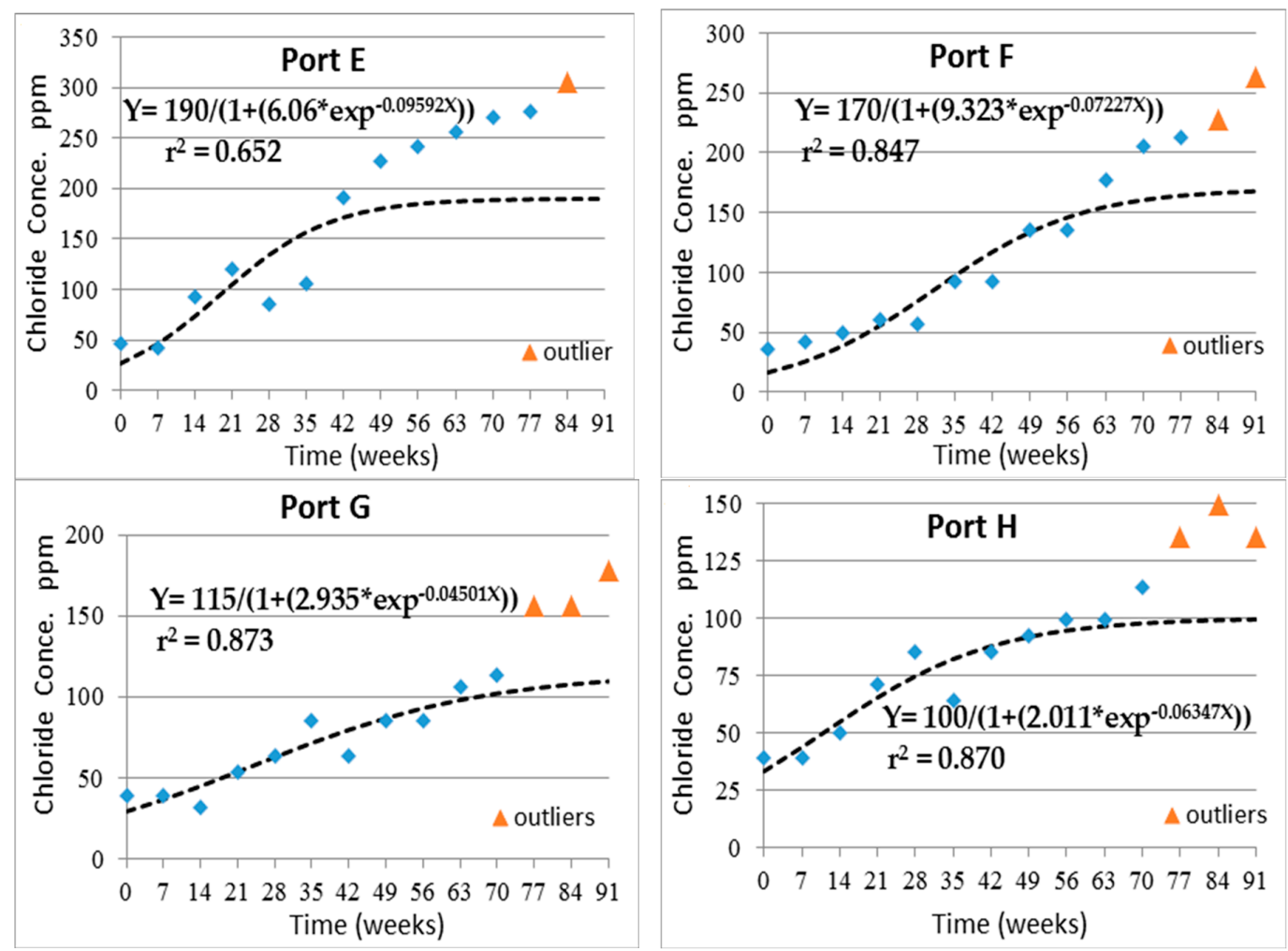

Figure 3. Logistic regression models developed for eight different portals (Port A through Port H) that represent depths in vadose zone from $6.25 \mathrm{~m}$ to $93.75 \mathrm{~m}$ below the surface with $25 \mathrm{~m}$ increment.

\subsection{Logarithmic Models}

The logistic model failed to capture the continuing rise in chloride concentrations through time in the lower portals. That is a function of the sigmoidal curves, which tended to level off too early. For long-term prediction of chloride ion movement at the different levels of soil profile (Port A through Port $\mathrm{H}$ ) logarithmic models were developed. Applying the logarithmic model to each portal, one can extend the timeline on the $\mathrm{x}$-axis until the concentration on the y-axis reaches the average $444 \mathrm{mg} / \mathrm{L}$ $\mathrm{Cl}^{-}$concentration of the septic waters. Figure 4 provides the results of the logarithmic models for Portals A through Port H. In each case, the log-model was extended until the concentration would reach the maximum steady state or $444 \mathrm{mg} / \mathrm{L} \mathrm{Cl}^{-}$. However, this assumes there is no dilution of the septic water, which is unlikely to happen except in extreme droughts.
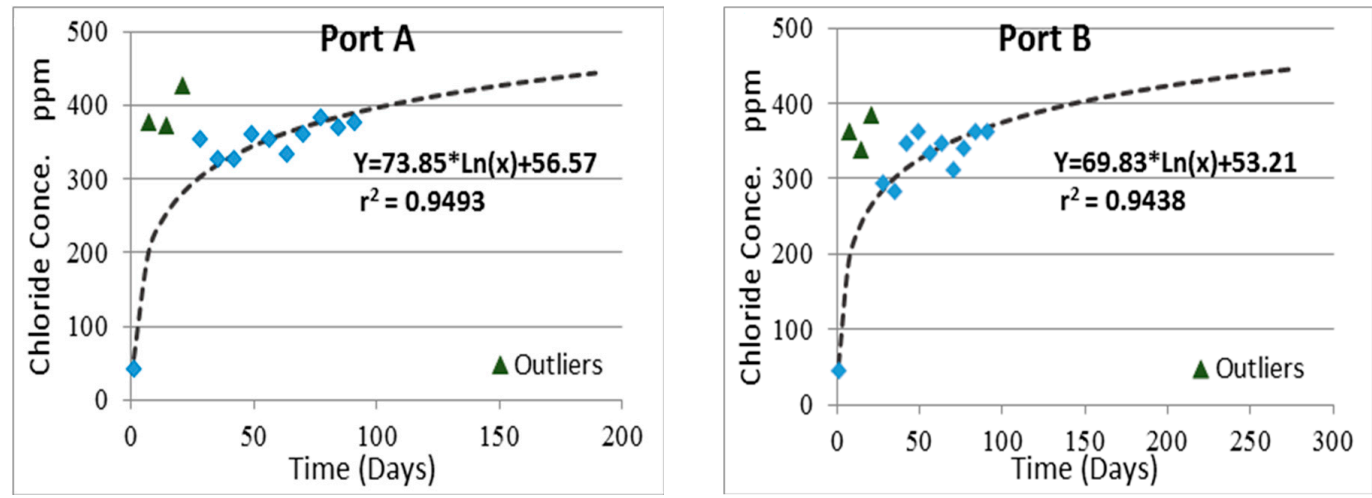

Figure 4. Cont. 

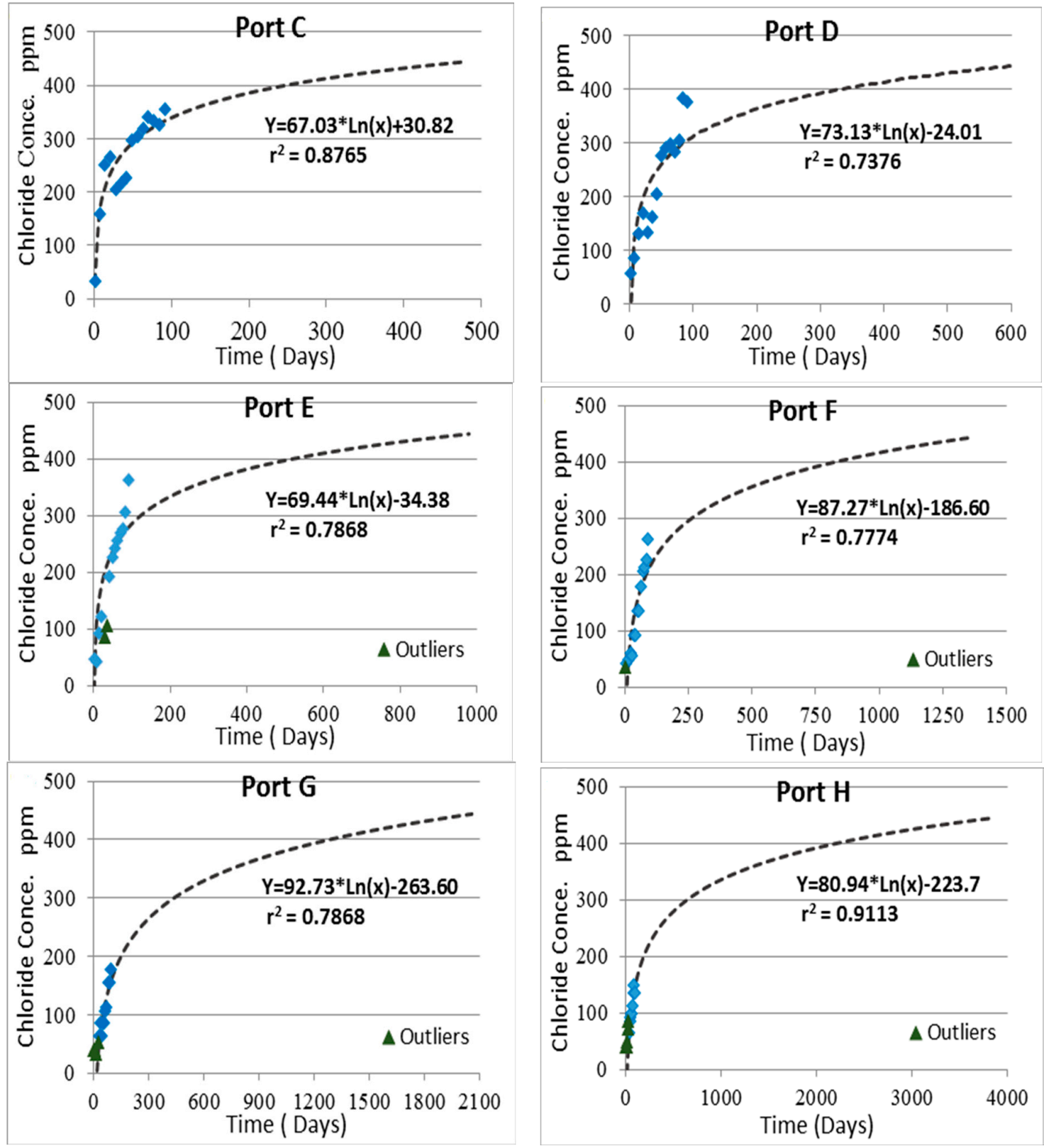

Figure 4. Logarithmic models developed for eight different portals (Port A through Port $\mathrm{H}$ ) that represent depths in vadose zone from $6.25 \mathrm{~m}$ to $93.75 \mathrm{~m}$ below the surface with $25 \mathrm{~m}$ increment.

Figure 5 combines the results of all the logarithmic models for each portal to predict when the chloride concentration will reach the septic water concentration of $444 \mathrm{ppm}$. As noted earlier, achieving this concentration assumes there is no dilution with percolating rainwater or mixing with groundwater.

Figure 6 provides a time chart for when each port would achieve the maximum $444 \mathrm{mg} / \mathrm{L} \mathrm{Cl}^{-}$ concentration, assuming no dilution. This assumption is not realistic. If there were no tap water to help push the septic water down, then it would never reach the bottom of the PVM chamber. It would be stuck by capillary action in the upper reaches of the PVM chamber. By applying tap water, which is equivalent to rain events, we saw that dilution and dispersion occurred and became more pronounced as the septic-water front moved further down the PVM chamber. 


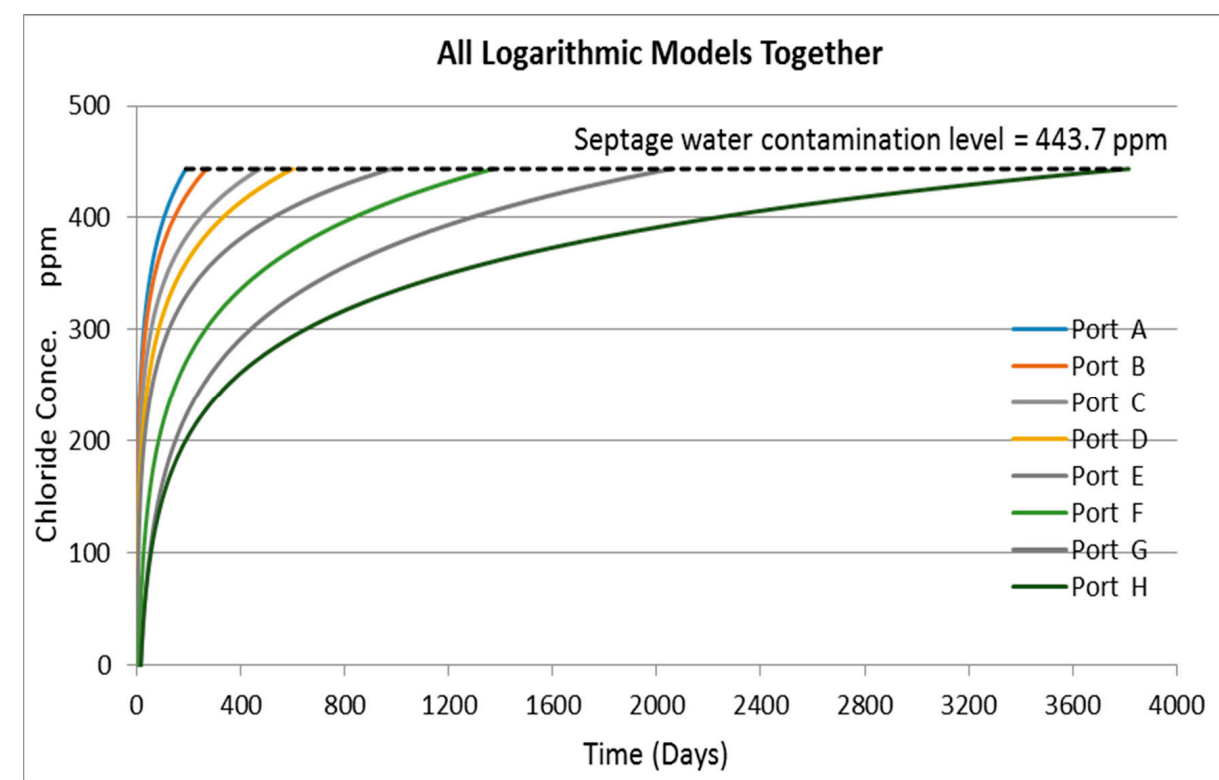

Figure 5. Logarithmic models for all ports together.

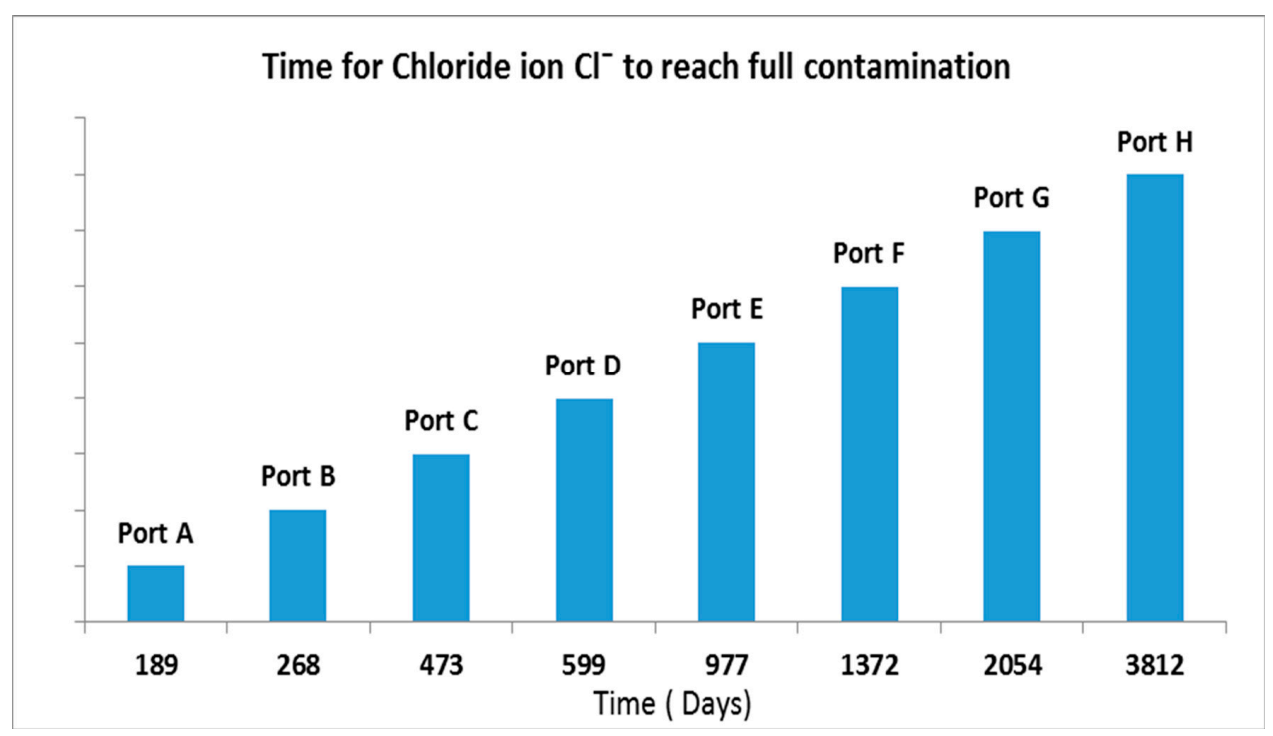

Figure 6. Time chart for chloride ion to reach background contamination level.

\section{Discussion}

The logistic regression and logarithmic models each have their strengths and weaknesses describing the fate and transport of chloride from septic waters through the vadose zone materials. The logistic model captures the dilution effect better than the logarithmic model, but fails to predict the continuously increasing concentration of chloride due to the nature of sigmoidal curves. The logarithmic model captures the continuing rise in chloride concentrations through time, but fails to adequately incorporate dilution from non-septic recharge waters. Using the data from Table 1, it appears the chloride concentrations reached $>250 \mathrm{mg} / \mathrm{L}$ in 6 of the 8 portals within 91 days, which is the secondary maximum contaminant level (SMCL) for chloride concentration in drinking water set by the United States Environmental Protection Agency [24]. It reached this $250 \mathrm{mg} / \mathrm{L}$ threshold in 7 days for portals A and B. It took 14 days to reach this concentration in portal C, and, 49 days for portal 
$\mathrm{D}$, and 63 days for portal E. Using the logarithmic model, we can predict that the concentration will reach $250 \mathrm{mg} / \mathrm{L}$ in portals F, G and $\mathrm{H}$ by 149,255 , and 348 days, respectively. If we used the logistic regression model for the same goal, it would appear that none of portals $\mathrm{E}, \mathrm{F}, \mathrm{G}$ and $\mathrm{H}$ would ever reach $250 \mathrm{mg} / \mathrm{L} \mathrm{Cl}^{-}$. The logistic regression models indicate that chloride concentration accumulates until it eventually reaches a maximum potential that decreases as you get further from the septic source. The logistic regression model predicts that the carrying capacity for each portal is Port A 358, Port B 341, Port C 287, Port D 240, Pot E 190, Port F 170, Port G 115, and Port H 100 mg/ $/ \mathrm{L} \mathrm{Cl}^{-}$.

The fate and transport of chloride ions through the vadose zone is probably best described by a combination of logistic regression model and logarithmic model. As long as septic waters containing an average of $444 \mathrm{mg} / \mathrm{L}$ chloride are leaking into the vadose zone, there will be a rise in chloride concentration. However, that rise in chloride will be tempered as the molecules move deeper into the vadose zone and blend with fresh rainwater or groundwater that is lower in concentration. Based on the constraints of the system, there probably is a maximum $\mathrm{Cl}^{-}$concentration that is lower than pure septic water due to dilution. However, as long as septic systems continue to leak and provide a regular input of water containing approximately $444 \mathrm{mg} / \mathrm{L} \mathrm{Cl}^{-}$, then it is reasonable to assume there will be a rise in chloride, especially during droughts.

One goal of this study was to provide a better understanding of how septic waters would move through the vadose zone in Duhok. If we extrapolate from this lab study using the 1:50 scale and the assumptions of a high density of septic systems in Duhok, it appears that septic waters and rainwater will reach the upper groundwater aquifer ( $\sim 100 \mathrm{~m}$ below surface) within two to three weeks. However, the septic waters will be diluted by the time they reach the water table. Other compounds found in septic waters, such as bacteria, viruses, nitrate, ammonia, phosphate, biological oxygen demand, detergents and surfactants will migrate at different rates than the chloride. However, this study shows the reason for concern is that more dangerous compounds can eventually reach the water table. The information gained by this study provides hydraulic engineers with a starting point to prioritize the areas in Duhok that should phase out household septic tanks and replace them with a modern sewer and wastewater treatment system to avoid septic contamination of utility well fields. Further studies are needed to determine the rate of horizontal migration in the water table. The rate of groundwater movement will affect how much dilution and blending occurs as the water moves towards the discharge point.

Acknowledgments: University of Duhok, Kurdistan Regional Government of Iraq has funded and fully supported this study through the split site grant of Ph.D. program. The fund covered the costs to publish in open access.

Author Contributions: Shawkat Kochary, Tom Byl and Bahzad Noori conceived and designed the experiments; Shawkat Kochary performed the experiments; Shawkat Kochary and Tom Byl analyzed the data; Shawkat Kochary, Tom Byl and Bahzad Noori contributed reagents/materials/analysis tools; Shawkat Kochary and Tom Byl wrote the paper.

Conflicts of Interest: The authors declare no conflict of interest. The founding sponsors had no role in the design of the study; in the collection, analyses, or interpretation of data; in the writing of the manuscript, and in the decision to publish the results.

\section{References}

1. Groundwater Protection. Principles and Practice (GP3), version 1.1; Environment Agency Horizon House: Bristol, UK, 2013.

2. Tazioli, A.; Conversini, P.; Peccerillo, A. Hydrogeological and geochemical characterisation of the Rock of Orvieto. Environ. Earth Sci. 2012, 66, 55-65. [CrossRef]

3. Comodi, G.; Cioccolanti, L.; Palpacelli, S.; Tazioli, A.; Nanni, T. Distributed generation and water production: A study for a region in central Italy. Desalination Water Treat. 2011, 31, 218-225. [CrossRef]

4. Cervi, F.; Ronchetti, F.; Doveri, M.; Mussi, M.; Marcaccio, M.; Tazioli, A. The use of stable water isotopes from rain gauges network to define the recharge areas of springs: Problems and possible solutions from case studies from the northern Apennines. Geoing. Ambient. Miner. 2016, 149, 19-26. 
5. Holland, J.P.; Asce, A.M. Development of a Comprehensive Modeling System for Remediation of Contaminated Groundwater. In Proceedings of the Hydraulic Engineering sessions at Water Forum, Baltimore, MD, USA, 2-6 August 1992.

6. Yates, M.V. Septic Tank Density and Groundwater Contamination. Groundwater 1985, 23, 586-591. [CrossRef]

7. U.S. Environmental Protection Agency (USEPA). EPA/600/P-95/002F a-c Exposure Factors Handbook; Final Report; U.S. Environmental Protection Agency: Washington, DC, USA, 1997.

8. Humphrey, M.D. Experimental Design of Physical Aquifer Models for Evaluation of Groundwater Remediation Strategies. Master's Thesis, Oregon State University, Corvallis, OR, USA, 1992.

9. Ojuri, O.O.; Ola, S.A. Estimation of contaminant transport parameters for a tropical sand in a sand tank model. Int. J. Environ. Sci. Technol. 2010, 7, 385-394. [CrossRef]

10. Mastrocicco, M.; Colombani, N.; Palpacelli, S.; Castaldelli, G. Large tank experiment on nitrate fate and transport: The role of permeability distribution. Environ. Earth Sci. 2011, 63, 903-914. [CrossRef]

11. Aquilanti, L.; Clementi, F.; Landolfo, S.; Nanni, T.; Palpacelli, S.; Tazioli, A. A DNA tracer used in column tests for hydrogeology applications. Environ. Earth Sci. 2013, 70, 3143-3154. [CrossRef]

12. Tazioli, A.; Palpacelli, S. Best tracer selection for hydrogeological investigations: Preliminary results from laboratory test. Ital. J. Groundw. 2013, 2, 7-12. [CrossRef]

13. Davis, S.N.; Thompson, G.M.; Bentley, H.W.; Stiles, G. Ground-Water Tracers-A Short Review. Groundwater 1980, 18, 14-23. [CrossRef]

14. Kanwar, R.S. Use of Tracers and Dyes to Assess Groundwater Contamination Potential for Glacial Till Aquifers. In Water-Quality Hydrology; Springer: Dordrecht, The Netherlands, 1996; pp. 177-186.

15. Mc Quillan, D. Groundwater quality impacts from on-site septic systems. In Proceedings of the 13th Annual Conference on National Onsite Wastewater Recycling Association, Albuquerque, NM, USA, 7-10 November 2004; pp. 6-18.

16. Mustafa, Y.T.; Ali, R.T.; Saleh, R.M. Monitoring and evaluating land cover change in the Duhok city, Kurdistan region-Iraq, by using remote sensing and GIS. Int. J. Eng. Invent. 2012, 1, 28-33.

17. Aqrawi, Z.A. Hydrological and Hydrogeological Study of the Etot-Aloka Basin, Dohuk Governorate (Iraq-Kurdistan Region). Ph.D. Dissertation, University of Salahaddin, Erbil, Iraq, 2003.

18. Eaton, A.D.; Clesceri, L.S.; Greenberg, A.E.; Franson, M.A.H. Standard Method for Examination of Water and Wastewater; American Public Health Association: Washington, DC, USA, 1998.

19. Das, B.M. Advanced Soil Mechanics, 3rd ed.; Taylor and Francis: New York, NY, USA, 2008; pp. $248-250$.

20. Ministry of Agriculture and Food, British Columbia Agriculture Council. Drainage Factsheet No. 541, Drain Filter and Envelopes; Ministry of Agriculture and Food, British Columbia Agriculture Council: Abbotsford, BC, Canada, 2000.

21. Bertram, G.E. An Experimental Investigation of Protective Filters; Soil Mechanics Series No. 7, Publication Number 267; Graduate School of Engineering, Harvard University: Cambridge, MA, USA, 1940.

22. Sherman, W.C. Filter Experiments and Design Criteria; Technical Memorandum, No. 3; U.S. Army Corps of Engineers, Army Engineer Water Ways Experiment Station: Vicksburg, MS, USA, 1953.

23. Kochary, S.A. The Impact of Septic Tanks on the Contamination of Groundwater in Upper Aquifer of Duhok City. Ph.D. Dissertation, University of Duhok, Kurdistan Region, Iraq, 2017.

24. United States Environmental Protection Agency. EPA 816-F-09-004 Drinking Water Contaminants: National Primary and Secondary Drinking Water Regulations; U.S. EPA: Washington, DC, USA, 2009.

(C) 2017 by the authors. Licensee MDPI, Basel, Switzerland. This article is an open access article distributed under the terms and conditions of the Creative Commons Attribution (CC BY) license (http:/ / creativecommons.org/licenses/by/4.0/). 